\title{
Hydroxyurea and blood transfusion therapy for Sickle cell disease in South Asia: inconsistent treatment of a neglected disease
}

\author{
Thamal Darshana ${ }^{1 *} \mathbb{D}$, David Rees ${ }^{2}$ and Anuja Premawardhena ${ }^{3}$
}

\begin{abstract}
Background: Hydroxyurea and blood transfusion therapies remain the main therapeutic strategies for Sickle cell disease. Preliminary data suggest substantial variation and inconsistencies in practice of these two therapeutic modalities in South Asia. In this systematic review we searched Medline, Cochrane library and Scopus for articles on usage of hydroxyurea and blood transfusion therapies for sickle cell disease in South Asia published in English between October 2005 and October 2020.

Results: We selected 41 papers: 33 from India, 3 from Sri Lanka, 2 each from Pakistan and Bangladesh and one from Nepal. Only 14 prospective trials focused on hydroxyurea therapy from which majority $(n=10 ; 71.4 \%)$ adopted fixed low dose $(10 \mathrm{mg} / \mathrm{kg} /$ day) regimen. With hydroxyurea therapy, 12 and 9 studies reported significant reductions in vaso-occlusive crises and transfusion requirement respectively. Severe anaemia (haemoglobin level $<6-7 \mathrm{~g} / \mathrm{dl}$ ) was the commonest indicator $(n=8)$ for transfusion therapy followed by vaso-occlusive crisis.
\end{abstract}

Conclusions: Published data on the hydroxyurea and transfusion therapies in South Asia are limited and heterogeneous. A clear gap of knowledge exists about the nature of the sickle cell disease in the Indian subcontinent particularly from countries outside India necessitating further evidence-based assessments and interventions.

Keywords: Sickle cell, South Asia, Hydroxyurea, Blood transfusion

\section{Background}

Sickle cell disease (SCD) is the commonest monogenic disorder characterized by a single mutation in the gene encoding for $\beta$-globin chain (HBB). The prevalence of the disease is high in sub-Saharan region of Africa, parts of Mediterranean, India and in the Middle East [1]. Remarkable variability of the clinical severity of SCD is widely acknowledged. The phenotypic variability could extend from those with very mild disease where patients may lead life without any need for treatment to individuals

\footnotetext{
*Correspondence: darshana@sjp.ac.lk

${ }^{1}$ Department of Medical Laboratory Sciences, Faculty of Allied Health

Sciences, University of Sri Jayewardenepura, Gangodawila 10250, Nugegoda, Sri Lanka

Full list of author information is available at the end of the article
}

with severe complicated disease with multiple disabling symptoms leading to premature death [2]. Five classical HBB haplotypes of SCD (Central African Republic, Benin, Senegal, Cameroon and Arab-Indian) have also described and are widely believed to contribute to the phenotypic variability largely through their effects on foetal haemoglobin (Hb F) levels [3]. Irrespective of the haplotype, evidence suggests that poverty influenced by lower socio-economic status could lead to adverse outcomes in the disease $[4,5]$. In the western world, more than $90 \%$ of children with SCD survive to adulthood whilst in Sub-Saharan Africa where there is the greatest burden of sickle cell anaemia estimates suggest that $50-80 \%$ of patients will die before adulthood [2].

In South Asia, the highest prevalence of the SCD is observed in India, where over 20 million patients with the 
disease are known to live. The burden of the disease in India is estimated to be second only to that of Africa with the highest frequency of $\beta$ s allele being found in a belt stretching across central India, from South-eastern Gujarat to South-western Odisha [6]. Although SCD has been reported from Pakistan, Sri Lanka, Nepal, Bangladesh and the Maldives, very little is known about the nature of SCD and the burden of the disease in these countries. There are few survival and mortality studies from South Asia. In a study conducted in Gujarat in India, about 20\% of children with SCD died by age of two and 30\% of children with SCD from tribal areas were noted to die before they come reached adulthood [7].

Several preventive and treatment approaches are available for management of SCD. Though no all-encompassing single guideline for management of SCD exists, expert committees have developed several guidelines on trial-based evidence and best practices [8-10]. These guidelines largely do not take into consideration the genotype nor the locality in which the patient is being treated.

Currently available treatment options for SCD include using of disease-modifying therapies like hydroxyurea (HU), blood transfusion and for a very few patients using near curative treatments like hematopoietic stem cell transplantation, and gene therapy. Supportive and preventive strategies like daily oral prophylactic penicillin up to the age of 5 years, opioid therapy to relief acute pain related to sickling event, non-opioid analgesics for chronic pain related to sickling and yearly Trans Cranial Doppler (TCD) examination from the ages 2-16 years to identify those who are vulnerable for stroke form the back bone of any management strategy $[8,11]$. In addition, voxeloter, L-glutamine and crizanlizumab have all been approved by U.S. Food and Drug Administration (FDA) recently, and are likely to expand the future therapeutics option for SCD [12].

The two main strategies of SCD management, namely $\mathrm{HU}$ and blood transfusion are used based on specific requirements. Blood transfusion therapy has been used for patients with SCD expecting that the normal haemoglobin would compensate for the adverse events generated by sickle haemoglobin $(\mathrm{Hb} \mathrm{S})$. Acute transfusion is generally performed to prevent / reverse severe anaemia or as an exchange transfusion for immediate reduction of sickle cell related acute complications [13]. Chronic transfusions are predominantly used for primary stroke prevention, or to prevent the recurrence of stroke among children with SCD, and to reduce recurrent vaso-occlusive crisis (VOC) and acute chest syndrome (ACS) when $\mathrm{HU}$ is ineffective [14-16]. HU, a cytotoxic drug, is used in the hope of altering the marrow-proliferation in favour the production of $\mathrm{Hb} \mathrm{F}$ over $\mathrm{Hb} \mathrm{S}$. Evidences suggest usage of $\mathrm{HU}$ reduces the incidence of acute pain, rate of acute chest syndrome, blood transfusion and overall mortality among patients with SCD $[17,18]$. Furthermore, HU decreases the numbers of platelets and white cells reducing harmful effects interceded by them in vascular injuries [19].

Preliminary literature assessment suggested that the management of SCD in South Asian countries appears to vary and is not consistent with the generally practiced guidelines for SCD [20,21]. We decided to conduct this review on the two main modalities of SCD treatment, namely blood transfusion and HU therapy across the different countries in South Asia to see how its applied in this region.

\section{Methods}

\section{Search strategy}

We searched databases of MEDLINE via Pubmed, Cochrane library (CENTRAL) and Scopus by Elsevier for studies published in English for past 15 years (between October 2005 and October 2020) using the following keywords in many combinations: Sickle cell, Sickle cell anaemia, Sickle cell disease, Blood transfusion, Hydroxycarbamide, Hydroxyurea, South Asia, India, Pakistan, Sri Lanka, Bangladesh, Nepal, Bhutan and Maldives.

\section{Inclusion criteria}

Prospective trials, descriptive studies, randomized placebo-controlled trials, reviews and case series reporting the practice of blood transfusion and Hydroxyurea therapies for SCD in seven South Asian countries (India, Pakistan, Sri Lanka, Bangladesh, Nepal, Bhutan and Maldives) were included in the present review.

\section{Exclusion criteria}

SCD related Studies that did not describe the practice of blood transfusion and Hydroxyurea therapies for SCD in aforementioned seven South Asian countries were excluded. Also, studies which were non-peer reviewed, unpublished and duplicate of a previously included study were excluded from the present review.

\section{Data extraction}

Two researchers (T.D. and A.P.) independently reviewed all abstracts of journal articles gathered by web search to identify papers that required full-text review. Final decision of selection was made via consensus. Furthermore, all articles were discussed with a third independent reviewer (D.R.). Data on the study setting, objectives, methods and results of each selected articles were extracted. Moreover, we methodically searched for any related papers in the reference lists of all articles selected. 


\section{Results}

We identified 860 papers through the search strategy, of which only 41 articles were in compliance with inclusion criteria were selected for qualitative synthesis (Fig. 1). Out of the 41 articles 33 (80.5\%) originated from India. In addition, there were 8 eligible papers including, 3 (7.3\%) from Sri Lanka and 2 each (4.9\%) from Pakistan, Bangladesh and one from Nepal (Fig. 2). Among the 8 studies selected outside India in South Asia, there were 7 case reports with 2 case studies each from Pakistan, Sri Lanka, Bangladesh and one from Nepal [22-28]. No eligible study was identified from Maldives and Bhutan. The majority of articles $(58.5 \% ; n=24)$ were published during the last 5 years (2015-2020). Designs of the 34 studies excluding case reports included prospective cohort studies $(n=15)$, descriptive studies $(n=7)$, retrospective analyses $(n=5)$, reviews $(n=3)$, prospective cohort comparison $(n=2)$, analytical cross-sectional $(n=1)$ and randomized placebo-controlled trial $(\mathrm{n}=1)$.

Of the 34 studies excluding case reports (Table 1), 14 Indian studies (41.2\%) focused on HU therapy while 6 studies $(17.6 \%)$ focused on transfusion therapy. Seven studies (20.6\%) were descriptive studies of clinical characteristics and 4 were observational cohort studies. Furthermore, 3 reviews described the clinical manifestation of SCD and the role of hydroxyurea in sickle

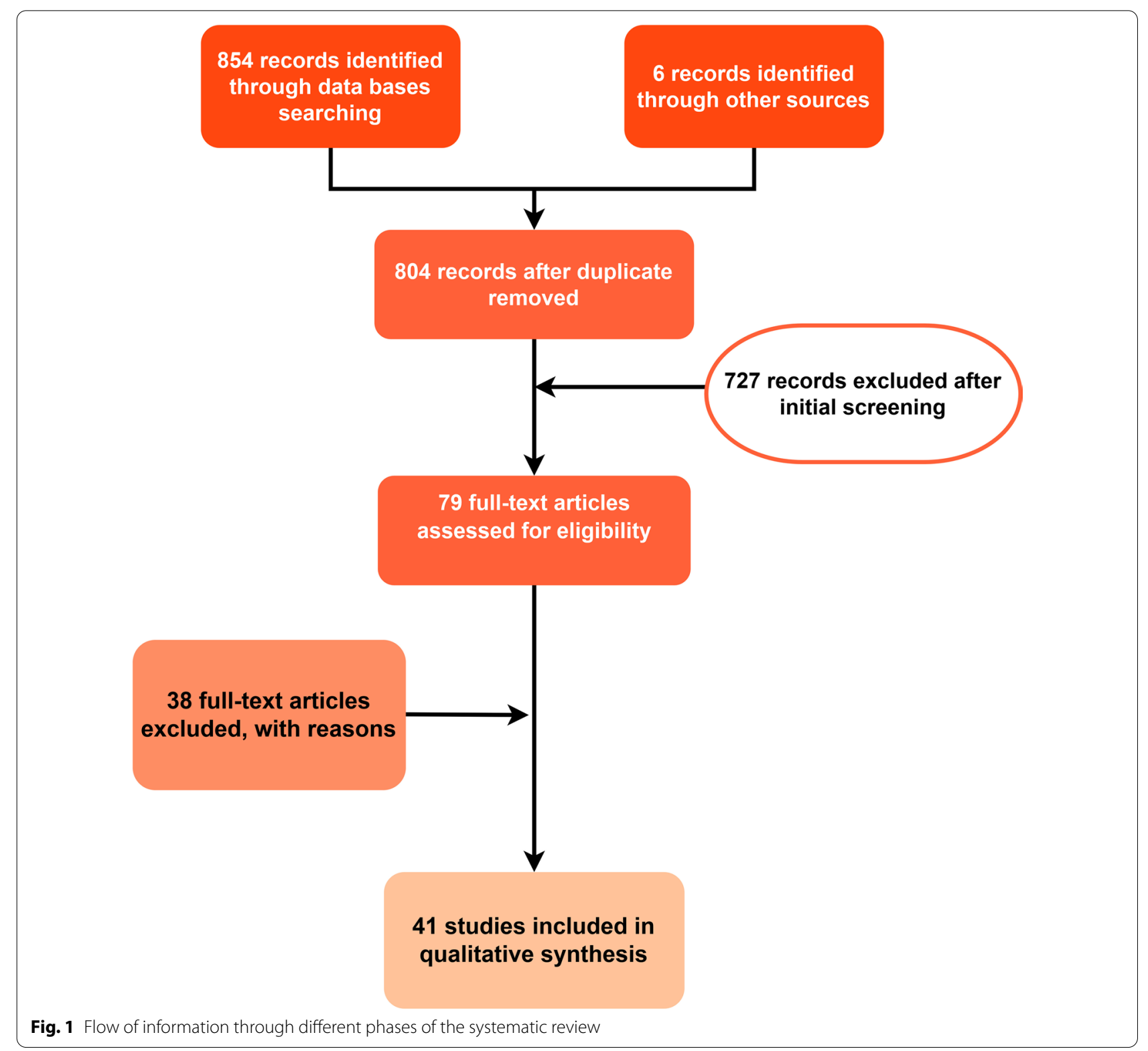




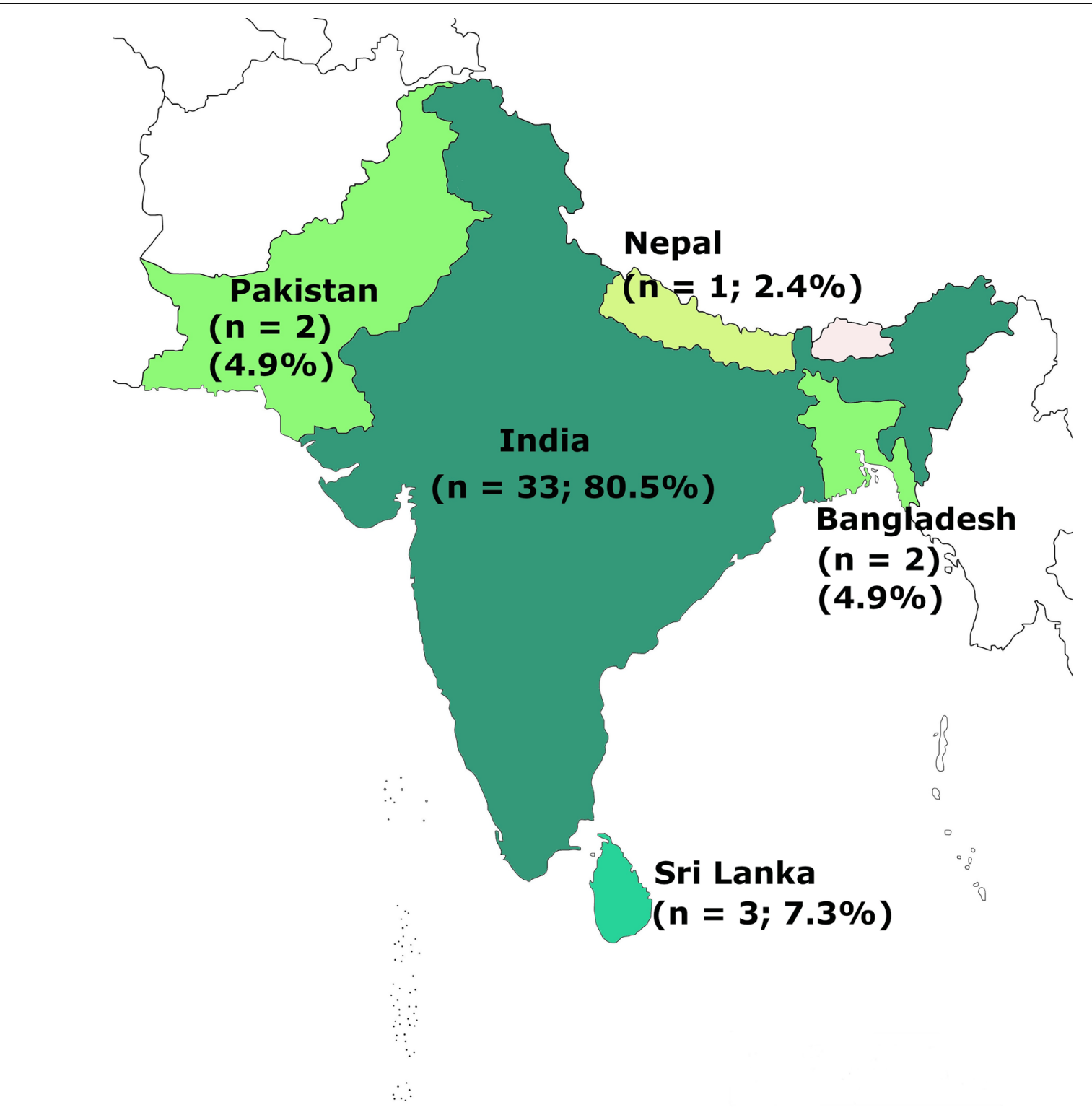

Fig. 2 Frequencies of data coming from each South Asian country

patients with Asian haplotype. Of the 14 prospective Indian studies focused on HU therapy, 12 (85.7\%) and $9(64.3 \%)$ studies noted significant reductions in VOC and blood transfusion requirement respectively with HU therapy. Likewise, 5 (35.7\%) studies reported significant reduction in hospitalization and 2 (14.3\%) studies noted significant improvement in ACS following the HU therapy. Of the 14 prospective studies focused on HU therapy, 13 analysed the haematological profiles of the participants. Significant improvement, particularly in haemoglobin level and $\mathrm{Hb} F$ level was observed in the majority $(\mathrm{n}=13 ; 100.0 \%, \mathrm{n}=10 ; 76.9 \%$ respectively). Of the 13 studies, $10(76.9 \%)$ noted significant reduction in WBC with mild-moderate neutropenia prompted by HU therapy. Deshpande et al., analysed the variation of WBC over different age groups and found HU induced leukopenia was significant only amidst SCD children below 10 years of age [20]. However, none of the studies observed severe neutropenia (neutrophil count $<0.5 \times 10^{9} / \mathrm{L}$ ) among the users of HU. Of the 13 studies that analysed haematological profile among HU users, 7 (53.8\%) reported significant reduction in platelet count with no severe case of thrombocytopenia (platelet count $<50 \times 10^{9} / \mathrm{L}$ ). Variations were identified 


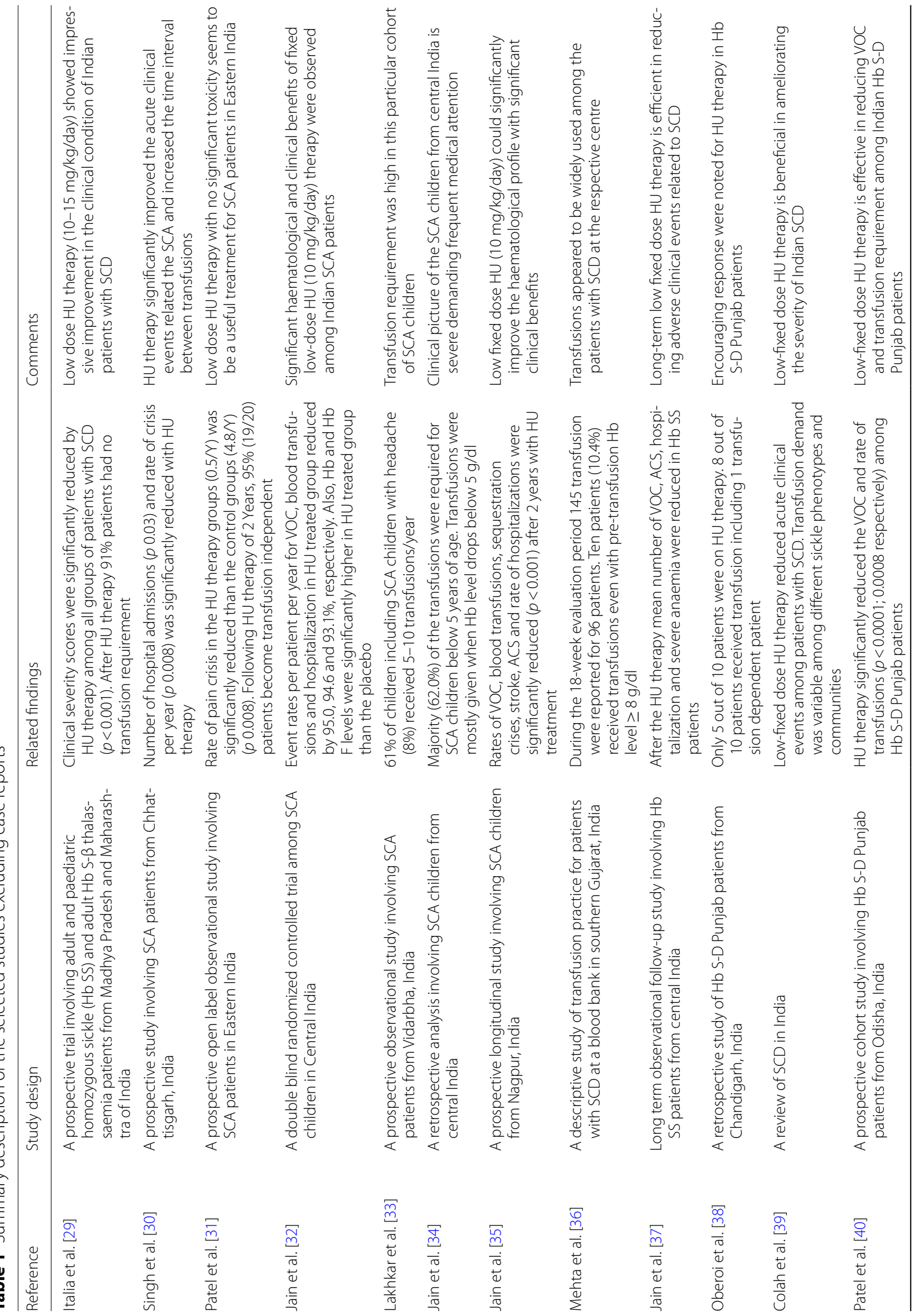




\begin{tabular}{|c|c|c|c|c|c|c|c|c|c|c|c|}
\hline & 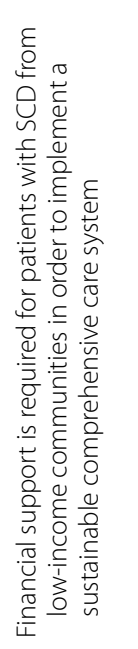 & 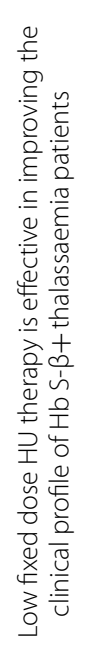 & 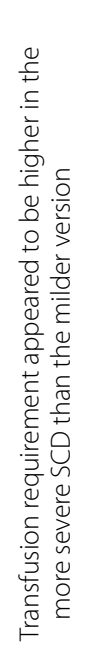 & 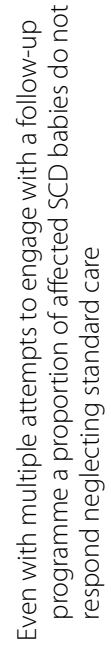 & 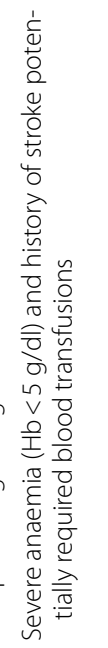 & 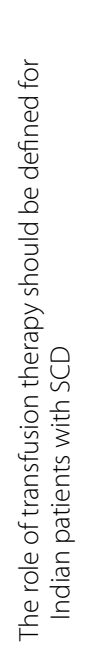 & 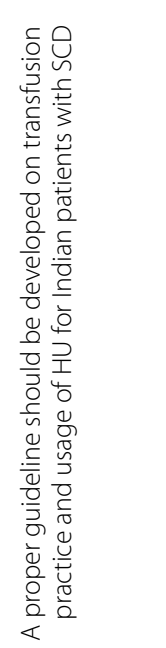 & 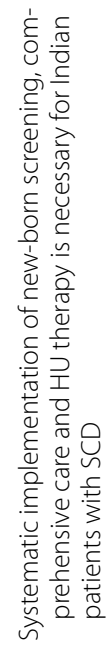 & 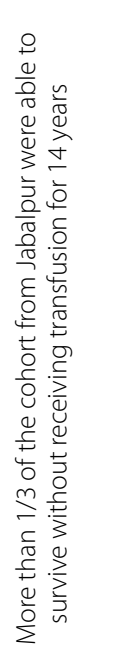 & 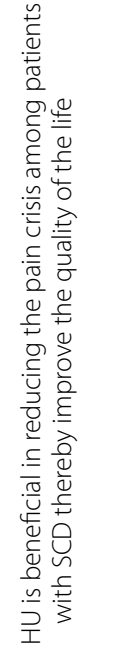 & 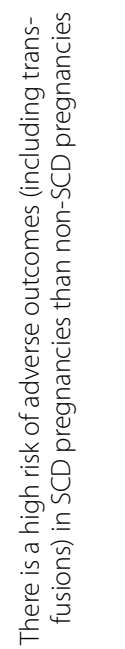 \\
\hline & 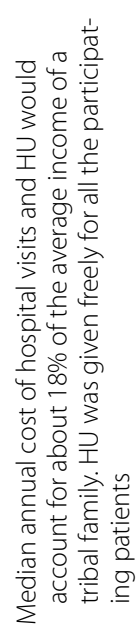 & 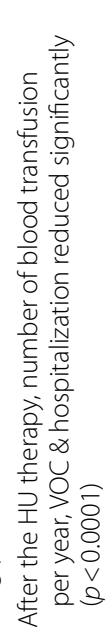 & 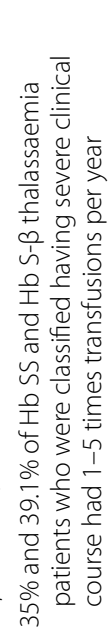 & 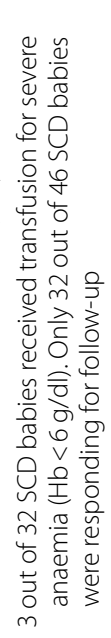 & 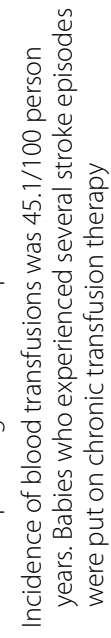 & 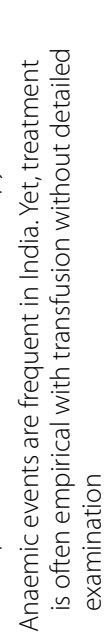 & 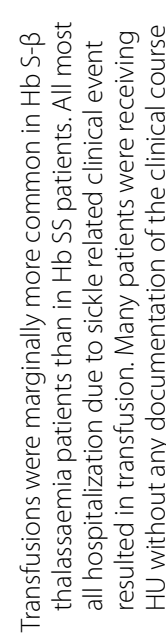 & 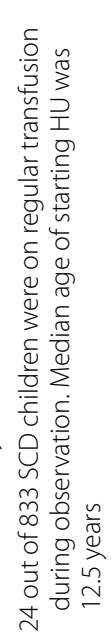 & 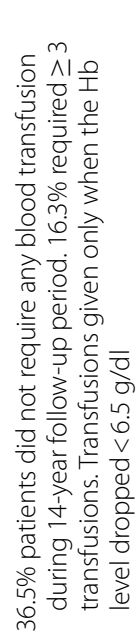 & 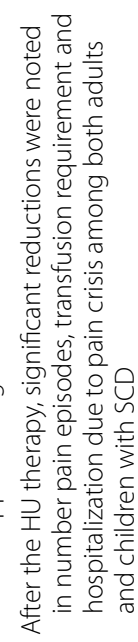 & 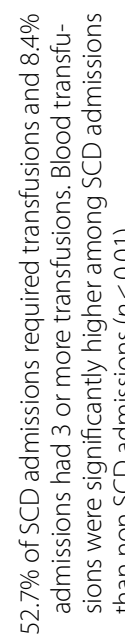 \\
\hline 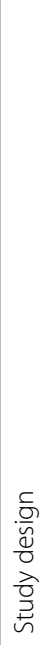 & 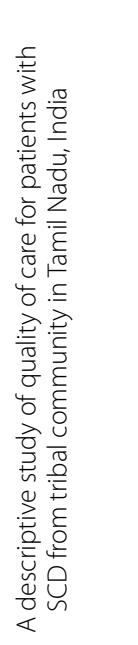 & 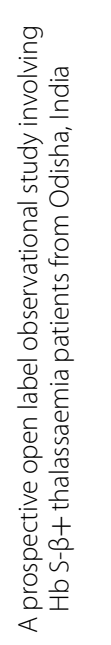 & 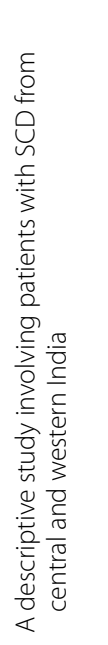 & 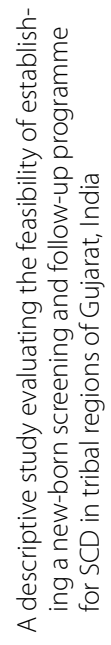 & 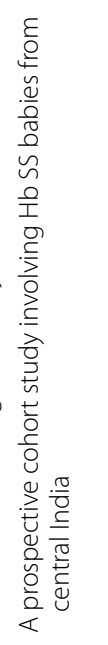 & 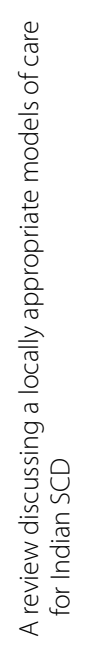 & 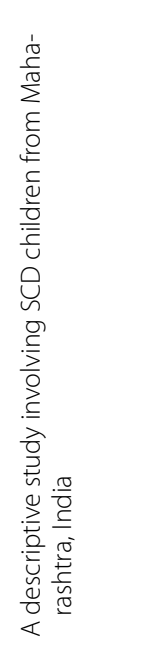 & 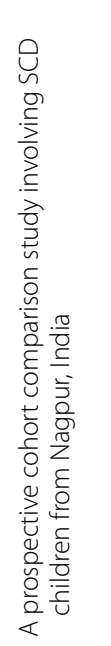 & 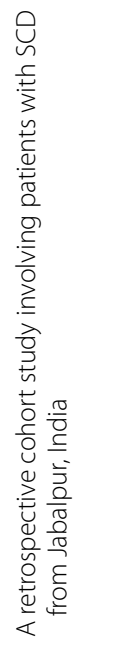 & 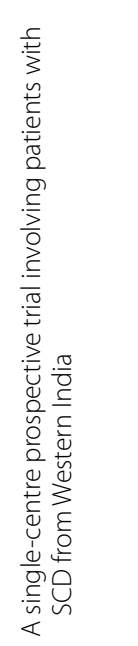 & 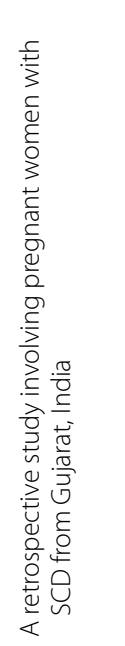 \\
\hline & 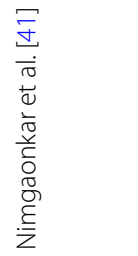 & 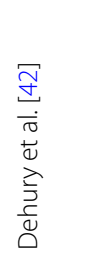 & 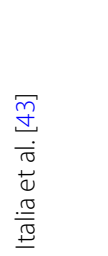 & 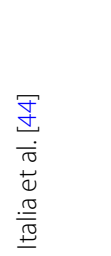 & 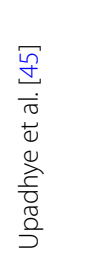 & 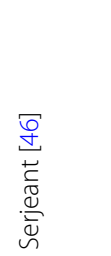 & 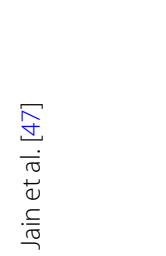 & 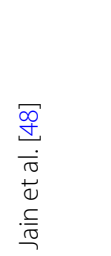 & 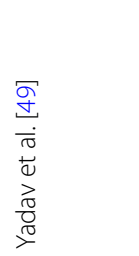 & 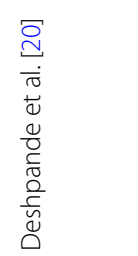 & 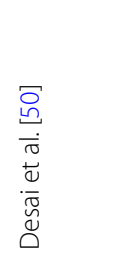 \\
\hline
\end{tabular}




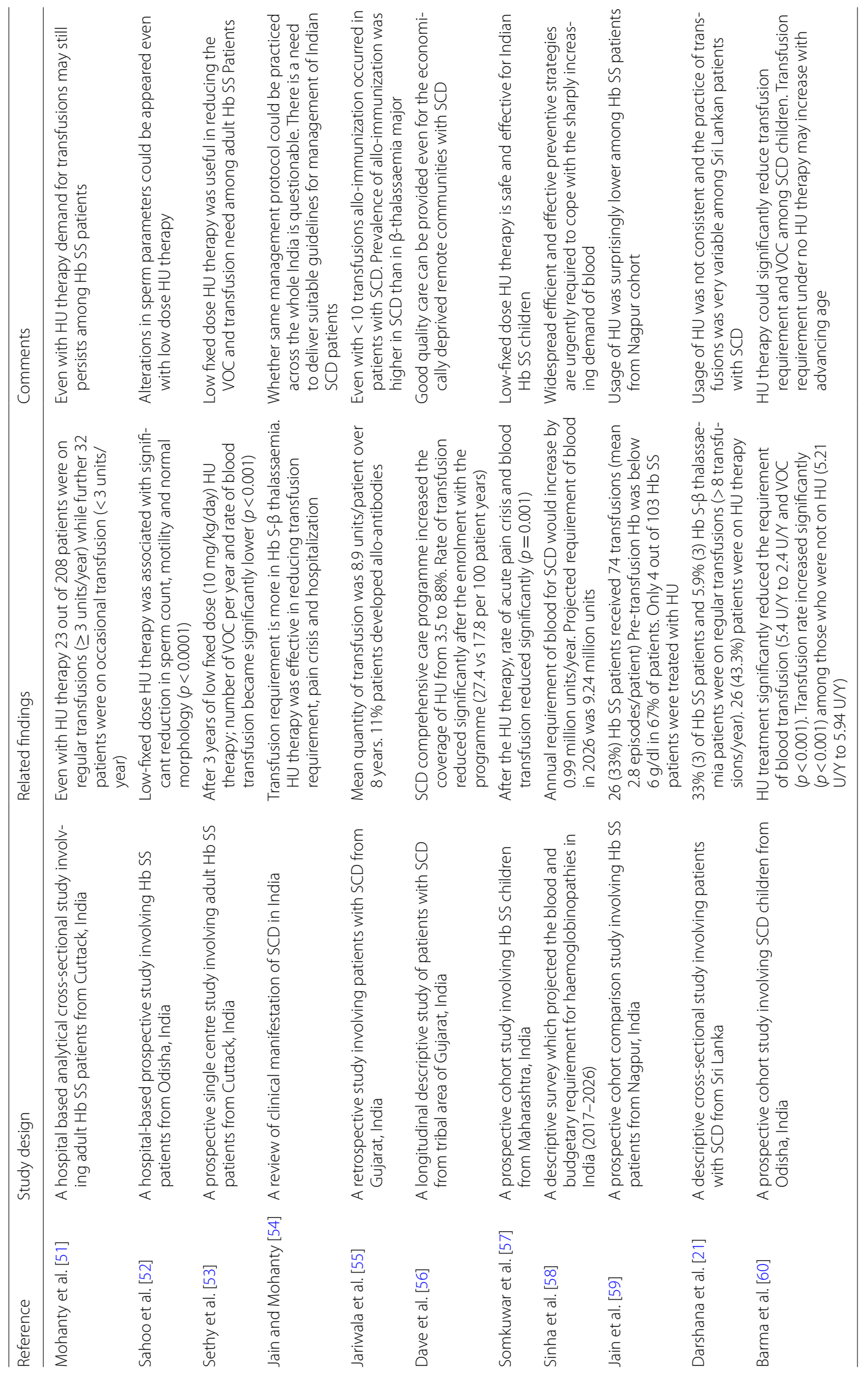


in the dose of $\mathrm{HU}$ given to patients with SCD. Eleven out of 14 prospective trials adopted fixed dose method and the remaining 3 trials adopted dose escalation regimen of HU. Of the studies adopted fixed dose method; 10 used low dose $(10 \mathrm{mg} / \mathrm{kg} /$ day $) \mathrm{HU}$ regimen and one adopted standard moderate dose $(20 \mathrm{mg} / \mathrm{kg} /$ day $)$ regimen. Of the studies which adopted dose escalation method, 2 started with low dose and increase up to high dose and one started with the standard moderate dose $(20 \mathrm{mg} / \mathrm{kg} /$ day $)$ and escalated by $5 \mathrm{mg} / \mathrm{kg} /$ day as adjudged by the treating clinician.

Indications for $\mathrm{HU}$ therapy have been elucidated in a previously published evidence-based review in which authors (Wong et al.) suggested 8 recommendations in a graded system for HU therapy among patients with SCD of all ages [61]. In the present study, we analysed the practice of recommendations made by Wong et al., among South Asian patients. Five studies practiced HU therapy in accordance with first recommendation (Grade 1A) which is the usage of $\mathrm{HU}$ when adult Sickle cell anaemia (SCA) patients' experience $\geq 3$ moderate to severe pain crises in a 12 -month period [29-31, 52, 53]. Seven studies practiced HU therapy in accordance with $2^{\text {nd }}, 3^{\text {rd }}$ and $4^{\text {th }}$ recommendations (Grade $1 \mathrm{~B}$ ) suggesting the usage of $\mathrm{HU}$ when adult SCA patient has a history of ACS or symptomatic anaemia; children with SCA experience $\geq 3$ moderate to severe pain crises in 12-month time period or having a history of ACS or symptomatic anaemia [29-32, 34, 35, 57]. In addition, five studies practiced HU therapy in accordance with recommendation 6 (usage of HU in SCA patients who have a history of stroke) [29, 30, 34, 35, 57], and two studies [29, 42] in accordance with recommendation 7 (usage of $\mathrm{HU}$ in adult $\mathrm{Hb} \mathrm{S}-\beta+$ thalassaemia patients who experience $\geq 3$ pain crises in 12-month period or having a history of ACS). Incidentally, 2 further studies reported the usage of $\mathrm{HU}$ in $\mathrm{Hb} \mathrm{S}-\mathrm{D}$ Punjab patients when they experience 3 or more VOC within 12-month period time [38, 40].
Of the 41 selected articles, only 9 reported the indications for transfusion therapy in sickle patients. Severe anaemia $(\mathrm{Hb}$ level $<6-7 \mathrm{~g} / \mathrm{dl})$ was the commonest indicator $(\mathrm{n}=8)$ for transfusion therapy followed by VOC $(n=2)$, stroke $(n=1)$, splenic sequestration $(n=1)$, pregnancy $(n=1)$ and headache $(n=1)$. Wide range of pretransfusion $\mathrm{Hb}$ levels were recorded in 2 studies. A study done in Central India reported a pre-transfusion $\mathrm{Hb}$ range which varied from 1.6 to $8.2 \mathrm{~g} / \mathrm{dl}$ whereas another study from Gujarat reported a pre-transfusion $\mathrm{Hb}$ range which varied from 2 to $10 \mathrm{~g} / \mathrm{dl}[36,59]$.

We attempted to assess issues relating to demand and availability of hydroxyurea and blood transfusion in the region. We were unable to find reliable information on hydroxyurea. Blood transfusion services are organised differently and the adequacy of blood donation and the percentage of voluntary donors are variable in the different countries in the South Asian region. The state has total control over the blood banks in Sri Lanka Maldives and Bhutan's while in India, Pakistan, Bangladesh and Nepal blood banking is heavily reliant on NonGovernmental organizations (NGO) and private blood banks though the state blood banks too exist. Overall, the demand for blood is not met in any of the countries except in Sri Lanka (Table 2). In 2017 India had the greatest absolute unmet blood unit requirement (40 964 075 units) from amongst 119 countries in the world [62].

\section{Discussion}

This systematic review of studies that evaluated the availability and therapeutic usage of both transfusion therapy and HU therapy for SCD in South Asia for the past 15 years identified that the available information in literature is limited and heterogeneous in nature. This precluded any effort of a proper meta-analysis. Even though presence of sickle haemoglobin had been reported from all South Asian countries, detailed studies of clinical outcomes were mostly available only from India. In most

Table 2 Estimated demand to supply ratio of blood in South Asian countries in 2017 according to the predictive model proposed by Nicholas Roberts and colleagues [62]

\begin{tabular}{llll}
\hline Country & Contributors of BTS & $\begin{array}{l}\text { Demand to supply ratio according to Roberts } \\
\text { et.al }\end{array}$ & Status remark \\
\hline India & State, Private and NGO & $3.0-5.0$ & Unmet demand \\
Pakistan & State, Private and NGO & $1.0-2.0$ & Unmet demand \\
Sri Lanka & State & $0.3-1.0$ & No unmet demand \\
Bangladesh & State, Private and NGO & $5.0-10.0$ & Unmet demand \\
Bhutan & State & $2.0-3.0$ & Unmet demand \\
Nepal & State, Private and NGO & $2.0-3.0$ & Unmet demand \\
Maldives & State & $1.0-2.0$ & Unmet demand \\
\hline
\end{tabular}

${ }^{a}$ Ratio of less than one indicates sufficient blood supply to meet the demand whereas ratio of more than one indicates unmet demand of blood 
instances literature was restricted to case studies or case reports. One reason for this paucity of data could be the low prevalence of sickle haemoglobin in some countries in South Asia. For instance, studies from Sri Lanka and Bangladesh have shown that the prevalence of sickle haemoglobin was relatively lower than that of other haemoglobinopathies in these regions [63-65]. Sickle haemoglobin has been reported at comparatively higher prevalence from the Tharu community of Western Nepal and Pakistan $[66,67]$. Although, the burden of the SCD in Tharu population had been acknowledged [68], no information was available of any evidence-based therapeutic strategy for patients with SCD from Nepal. The situation in Pakistan was not much different to that from Nepal. Other than the reports indicating the presence of SCD in Khyber Pakhtunkhwa, Karachi and Balochistan [69-71], nothing much is known about the clinical course of the disease and therapeutic scenarios currently in place for patients with SCD from these areas.

Even with limited data, the present review identified several indications for HU therapy for patients with SCD in India including, $\geq 3$ pain crises/year, history of ACS, stroke and symptomatic severe anaemia. Nevertheless, in real world practice the circumstances could be quite different as explained by Jain et al.; in Maharashtra many patients with SCD have undergone HU therapy from the first clinical visit irrespective of their symptoms [47]. Moreover, the usage of $\mathrm{HU}$ for infants and children age 9 months or older who are asymptomatic or having infrequent pain episode has not adequately analysed among Indian patients. Therapeutic usage of HU for SCD have also been noted in couple of case reports from Pakistan, Bangladesh, Nepal and one descriptive cross-sectional study from Sri Lanka [21, 22, 26, 28]. However, particulars of different dosing regimens in practice, toxicities and detailed response to HU therapy is largely unknown. Despite all the known benefits of $\mathrm{HU}$ improving the quality of life, clinicians' prescription and patient compliance of HU seems below par in the Indian subcontinent. In their recent review Jain and Mohanty described that the poor compliance with $\mathrm{HU}$ among Indian patients may be due to physician's concerns of potential long-term mutagenic effects and lack of familiarity of primary attending medical staff with HU therapy [54]. Inconsistency in adherence with HU therapy owing to the lack of familiarity of primary care medical staff has also been noted in a recent Sri Lankan study in which authors recommended the development of national guidelines for management of patients with SCD [21]. Socio-economic status and the financial capabilities of the sickle patients largely influence the affordability of standard care including $\mathrm{HU}$ in economically disadvantaged settings in the Indian subcontinent. Nevertheless, country wise data and statistics about the availability and affordability of $\mathrm{HU}$ for sickle patients are not available in South Asia. Incidentally, initiations have been taken to deliver comprehensive care including free outpatient medication such as $\mathrm{HU}$ and pneumococcal vaccination for economically disadvantaged rural SCD communities in India with encouraging outcomes $[41,56]$. However, no evidence is available about such initiatives outside India in South Asia.

Recent trials assessing the role of $\mathrm{HU}$ in preventing primary overt ischaemic stroke in patients with SCD of African origin found it to be effective [72, 73]. However, no such information is available about the efficiency of $\mathrm{HU}$ therapy in averting primary overt ischaemic stroke in patients with SCD of Indian origin.

Transfusion therapy for SCD has been used for many years and appears to be effective in primary and secondary prevention of stroke among sickle patients $[74,75]$. The present review identified that transfusion therapy is in use for SCD in South Asia though there was paucity of information from outside India. However, indications of transfusion therapy have been described in limited number of studies. Available data suggests that transfusion was mostly given for severe anaemia (haemoglobin level below $6-7 \mathrm{~g} / \mathrm{dl}$ ). In addition, couple of Indian studies reported that transfusions were given when patients experience VOC [34,38] and headaches [33]. Nevertheless, transfusion therapy for SCD seemed to be widely used in India without clear indications which could inevitably result in many deleterious clinical outcomes in patients and increase the financial burden. A study from Gujarat reported numerous transfusions for sickle patients with no clear diagnosis and justification [36]. Discrepancies and inconsistencies in transfusion practice for SCD has also been noted in Sri Lanka in which authors highlighted the disadvantage of not having a clear guideline [21]. Demand of blood for SCD transfusions is increasing in India by 0.99 million units per year. In line with projections by 2026 the total blood requirement for patients with SCD would reach 9.24 million units which would account for considerable portion of the total amount of donated blood [58]. There is however no data relating to blood requirements for patients with SCD outside India in the South Asian region.

\section{Conclusions}

In summary, both HU and transfusion therapy for South Asian patients with SCD would benefit more from further evidence-based assessments and interventions. Fixed-low dose HU therapy $(10 \mathrm{mg} / \mathrm{kg} /$ day $)$, which has yielded promising results among Indian patients with SCD may be applicable for sickle patients with Indian origin from other South Asian countries. Similarly, the role of transfusion therapy for SCD should be well defined 
in different sickle communities of Indian subcontinent. Initiation has been taken by India introducing "National Health Mission Guidelines on Haemoglobinopathies" which included basic guidance on $\mathrm{HU}$ and transfusion therapy for SCD [76]. There is a clear gap of knowledge about the nature of SCD in the Indian subcontinent particularly from countries outside India. Practice of the main therapeutic modalities such as transfusion and $\mathrm{HU}$ therapies, diagnosis and different patient management strategies of SCD have not been adequately described in these regions, suggesting the compelling need for more research and evidence-based policy making.

\section{Abbreviations}

SCD: Sickle cell disease; Hb F: Foetal haemoglobin; HU: Hydroxyurea; TCD: Trans Cranial Doppler; Hb S: Sickle haemoglobin; VOC: Vaso-occlusive crisis; ACS: Acute chest syndrome; SCA: Sickle cell anaemia; NGO: Non-Governmental Organization; Hb SS: Homozygous sickle.

\section{Acknowledgements}

Not applicable.

\section{Authors' contributions}

TD reviewed the literature, extracted and analysed the data and wrote the original draft of the manuscript. DR participated in conceptualization and revising the manuscript. AP participated in conceptualization revising the manuscript and overall supervision. All authors read and approved the final manuscript.

\section{Funding}

This research did not receive any specific grant from funding agencies in the public, commercial, or not-for-profit sectors.

\section{Availability of data and materials}

Data sharing not applicable to this article as no datasets were generated or analysed during the current study.

\section{Declarations}

Ethics approval and consent to participate

Not applicable.

\section{Consent for publication}

Not applicable.

\section{Competing interests}

The authors declare that they have no competing interests.

\section{Author details}

${ }^{1}$ Department of Medical Laboratory Sciences, Faculty of Allied Health Sciences, University of Sri Jayewardenepura, Gangodawila 10250, Nugegoda, Sri Lanka. ${ }^{2}$ King's College Hospital, London, UK. ${ }^{3}$ Department of Medicine, University of Kelaniya, Kelaniya, Sri Lanka.

Received: 7 January 2021 Accepted: 16 March 2021

Published online: 23 March 2021

\section{References}

1. Kato GJ, Piel FB, Reid CD, Gaston MH, Ohene-Frempong K, Krishnamurti L, et al. Sickle cell disease. Nat Rev Dis Primers. 2018;4:18010

2. Makani J, Cox SE, Soka D, Komba AN, Oruo J, Mwamtemi H, et al. Mortality in sickle cell anemia in Africa: a prospective cohort study in Tanzania. PLoS ONE. 2011;6(2):e14699-e.
3. Piel FB, Hay SI, Gupta S, Weatherall DJ, Williams TN. Global burden of sickle cell anaemia in children under five, 2010-2050: modelling based on demographics, excess mortality, and interventions. PLoS Med. 2013;10(7):e1001484.

4. Bello-Manga H, Galadanci AA, Abdullahi S, Ali S, Jibir B, Gambo S, et al. Low educational level of head of household, as a proxy for poverty, is associated with severe anaemia among children with sickle cell disease living in a low-resource setting: evidence from the SPRING trial. Br J Hematol. 2020;190(6):939-44.

5. Fernandes TAADM, Medeiros TMD, Alves JJP, Bezerra CM, Fernandes JV, Serafim ÉSS, et al. Socioeconomic and demographic characteristics of sickle cell disease patients from a low-income region of northeastern Brazil. Rev Bras Hematol Hemoter. 2015;37(3):172-7.

6. Hockham C, Bhatt S, Colah R, Mukherjee MB, Penman BS, Gupta S, et al. The spatial epidemiology of sickle-cell anaemia in India. Sci Rep. 2018;8(1):17685.

7. Saxena D, Yasobant S, Golechha M. Situational analysis of sickle cell disease in Gujarat, India. Indian J Commun Med. 2017;42(4):218-21.

8. Brandow AM, Carroll CP, Creary S, Edwards-Elliott R, Glassberg J, Hurley RW, et al. American Society of Hematology 2020 guidelines for sickle cell disease: management of acute and chronic pain. Blood Adv. 2020;4(12):2656-701.

9. Chou ST, Alsawas M, Fasano RM, Field JJ, Hendrickson JE, Howard J, et al. American Society of Hematology 2020 guidelines for sickle cell disease: transfusion support. Blood Adv. 2020;4(2):327-55.

10. Nigeria FRO. National guideline for the control and management of sickle cell disease. In: Nigeria FMoH, editor. Abuja: Federal Republic of Nigeria; 2014

11. Yawn BP, Buchanan GR, Afenyi-Annan AN, Ballas SK, Hassell KL, James AH, et al. Management of sickle cell disease: summary of the 2014 evidencebased report by expert panel members. JAMA. 2014:312(10):1033-48.

12. AIDallal SM. Voxelotor: a ray of hope for sickle disease. Cureus. 2020;12(2):e7105

13. Davis BA, Allard S, Qureshi A, Porter JB, Pancham S, Win N, et al. Guidelines on red cell transfusion in sickle cell disease. Part I: principles and laboratory aspects. Br J Hematol. 2017;176(2):179-91.

14. Inati A, Mansour AG, Sabbouh T, Amhez G, Hachem A, Abbas HA. Transfusion therapy in children with sickle cell disease. J Pediatr Hematol Oncol. 2017;39(2):126-32.

15. Wang WC, Dwan K. Blood transfusion for preventing primary and second ary stroke in people with sickle cell disease. Cochrane Database Syst Rev. 2013:11:003146.

16. Howard J. Sickle cell disease: when and how to transfuse. Hematol Am Soc Hematol Educ Program. 2016;2016(1):625-31.

17. Charache S, Terrin ML, Moore RD, Dover GJ, Barton FB, Eckert SV, et al. Effect of hydroxyurea on the frequency of painful crises in sickle cell anemia. J Med. 1995;332(20):1317-22.

18. Steinberg MH, Barton F, Castro O, Pegelow CH, Ballas SK, Kutlar A, et al. Effect of hydroxyurea on mortality and morbidity in adult sickle cell anemia: risks and benefits up to 9 years of treatment. JAMA. 2003:289(13):1645-51.

19. Platt OS. Hydroxyurea for the treatment of sickle cell anemia. New Engl J Med. 2008:358(13):1362-9.

20. Deshpande SV, Bhatwadekar SS, Desai P, Bhavsar T, Patel A, Koranne A, et al. Hydroxyurea in sickle cell disease: our experience in western India. Indian J Hematol Blood Transfusion Off J Indian Soc Hematol Blood Transfusion. 2016;32(2):215-20.

21. Darshana T, Bandara D, Nawarathne U, de Silva U, Costa Y, Pushpakumara $\mathrm{K}$, et al. Sickle cell disease in Sri Lanka: clinical and molecular basis and the unanswered questions about disease severity. Orphanet J Rare Dis. 2020;15(1):177

22. Afzal H, Umair SF. Haemoglobin sickle D disease: a presentation with ischaemic stroke. J Pak Med Assoc. 2016;66:348-50.

23. Janjua T, Haider S, Raza N. Multiple complications in sickle cell anaemia. J Pak Med Assoc. 2018;68:154-6.

24. Premathilaka L, Lakmini M, Darshana T, Nawaratne S, Mettananda S, De Silva S, et al. Stroke in sickle beta thalassemia - a case report highlighting pitfalls in management in a low prevalence country. Sri Lanka J Med. 2018;26:55

25. Thalagahage $\mathrm{KH}$, Jayaweera JAAS, Kumbukgolla W, Perera $\mathrm{N}$, Thalagahage E, Kariyawasam J, et al. HbS/D-Punjab disease: report of 3 cases from 
Sri Lanka. Indian J Hematol Blood Transfusion Off J Indian Soc Hematol Blood Transfusion. 2018;34(2):350-2.

26. Mollah M, Rahman E, Islam S, Morshed A, Munmun F, Shohel M. A young child with sickle cell beta thalassemia: a case report and review of literatures. J Dhaka Med College. 2013;21 (2):245-9.

27. Aziz M, Sarkar S, Rahman F, Biswas S, Baqi S, Begum M. Atypical presentation of sickle cell disease. Bangabandhu Sheikh Mujib Med Univ J. 2017;10:27.

28. Lamsal KS. Sickle cell Anemia with avascular necrosis of femur being managed as rheumatic fever. J Inst Med Nepal. 2013;34:37-9.

29. Italia K, Jain D, Gattani S, Jijina F, Nadkarni A, Sawant P, et al. Hydroxyurea in sickle cell disease-a study of clinico-pharmacological efficacy in the Indian haplotype. Blood Cells Mol Dis. 2009;42(1):25-31.

30. Singh H, Dulhani N, Kumar BN, Singh P, Tiwari P. Effective control of sickle cell disease with hydroxyurea therapy. Indian J Pharmacol. 2010:42(1):32-5.

31. Patel DK, Mashon RS, Patel S, Das BS, Purohit P, Bishwal SC. Low dose hydroxyurea is effective in reducing the incidence of painful crisis and frequency of blood transfusion in sickle cell anemia patients from eastern India. Hemoglobin. 2012;36(5):409-20.

32. Jain DL, Sarathi V, Desai S, Bhatnagar M, Lodha A. Low fixed-dose hydroxyurea in severely affected Indian children with sickle cell disease. Hemoglobin. 2012;36(4):323-32.

33. Lakhkar BB, Lakhkar BN, Vaswani P. Transcranial Doppler study among children with sickle cell anaemia vs normal children. J Nepal Paediatr Soc. 2012;32:146-9.

34. Jain D, Italia K, Sarathi V, Ghoshand K, Colah R. Sickle cell anemia from central India: a retrospective analysis. Indian Pediatr. 2012;49(11):911-3.

35. Jain DL, Apte M, Colah R, Sarathi V, Desai S, Gokhale A, et al. Efficacy of fixed low dose hydroxyurea in Indian children with sickle cell anemia: a single centre experience. Indian Pediatr. 2013;50(10):929-33.

36. Mehta V, Mistry A, Raicha B, Italia Y, Serjeant G. Transfusion in sickle cell disease: experience from a Gujarat centre. Indian J Pediatr. 2014;81(3):234-7.

37. Jain DL, Krishnamurti L, Sarathi V, Desai S, Gokhale A. Long term safety and efficacy of low fixed dose hydroxyurea in pediatric patients with sickle cell anemia: a single center study from central India. Blood. 2013;122(21):1000

38. Oberoi S, Das R, Trehan A, Ahluwalia J, Bansal D, Malhotra P, et al. HbSDPunjab: clinical and hematological profile of a rare hemoglobinopathy. Pediatr Hematol Oncol. 2014;36(3):e140-4.

39. Colah R, Mukherjee M, Ghosh K. Sickle cell disease in India. Curr Opin Hematol. 2014;21(3):215-23.

40. Patel S, Purohit P, Mashon RS, Dehury S, Meher S, Sahoo S, et al. The effect of hydroxyurea on compound heterozygotes for sickle cell-hemoglobin D-Punjab-a single centre experience in eastern India. Pediatr Blood Cancer. 2014;61(8):1341-6.

41. Nimgaonkar V, Krishnamurti L, Prabhakar H, Menon N. Comprehensive integrated care for patients with sickle cell disease in a remote aboriginal tribal population in southern India. Pediatr Blood Cancer. 2014;61(4):702-5.

42. Dehury S, Purohit P, Patel S, Meher S, Kullu BK, Sahoo LK, et al. Low and fixed dose of hydroxyurea is effective and safe in patients with $\mathrm{HbS} \beta+$ thalassemia with IVS1-5(G $\rightarrow$ C) mutation. Pediatric Blood Cancer. 2015:62(6):1017-23.

43. Italia K, Kangne H, Shanmukaiah C, Nadkarni AH, Ghosh K, Colah RB. Variable phenotypes of sickle cell disease in India with the Arab-Indian haplotype. Br J Haematol. 2015;168(1):156-9.

44. Italia Y, Krishnamurti L, Mehta V, Raicha B, Italia K, Mehta P, et al. Feasibility of a newborn screening and follow-up programme for sickle cell disease among South Gujarat (India) tribal populations. J Med Screen. 2015;22(1):1-7.

45. Upadhye DS, Jain DL, Trivedi YL, Nadkarni AH, Ghosh K, Colah RB. Neonatal screening and the clinical outcome in children with sickle cell disease in central India. PLoS ONE. 2016;11(1):e0147081.

46. Serjeant GR. Evolving locally appropriate models of care for indian sickle cell disease. Indian J Med Res. 2016;143(4):405-13.

47. Jain D, Warthe V, Dayama P, Sarate D, Colah R, Mehta P, et al. Sickle cell disease in central India: a potentially severe syndrome. Indian J Pediatr. 2016;83(10):1071-6.
48. Jain D, Arjunan A, Sarathi V, Jain H, Bhandarwar A, Vuga M, et al. Clinical events in a large prospective cohort of children with sickle cell disease in Nagpur, India: evidence against a milder clinical phenotype in India. Pediatr Blood Cancer. 2016;63(10):1814-21

49. Yadav R, Lazarus M, Ghanghoria P, Singh M, Gupta RB, Kumar S, et al. Sickle cell disease in Madhya Pradesh, Central India: a comparison of clinical profile of sickle cell homozygote vs sickle-beta thalassaemia individuals. Hematology (Amsterdam, Netherlands). 2016;21(9):558-63.

50. Desai G, Anand A, Shah P, Shah S, Dave K, Bhatt H, et al. Sickle cell disease and pregnancy outcomes: a study of the community-based hospital in a tribal block of Gujarat, India. J Health Popul Nutr. 2017;36(1):3.

51. Mohanty P, Jena RK, Sethy S. Variability of iron load in patients of sickle cell anaemia (HbSS): a study from Eastern India. J Clin Diagn Res. 2017;11(3):19-22.

52. Sahoo LK, Kullu BK, Patel S, Patel NK, Rout P, Purohit P, et al. Study of seminal fluid parameters and fertility of male sickle cell disease patients and potential impact of hydroxyurea treatment. J Assoc Physicians India. 2017;65(6):22-5.

53. Sethy S, Panda T, Jena RK. Beneficial effect of low fixed dose of hydroxyurea in vaso-occlusive crisis and transfusion requirements in adult hbss patients: a prospective study in a tertiary care center. Indian $J$ Hematol Blood Transfusion Off J Indian Soc Hematol Blood Transfusion. 2018;34(2):294-8

54. Jain D, Mohanty D. Clinical manifestations of sickle cell disease in India: misconceptions and reality. Curr Opin Hematol. 2018;25(3):171-6.

55. Jariwala K, Mishra K, Ghosh K. Comparative study of alloimmunization against red cell antigens in sickle cell disease \& thalassaemia major patients on regular red cell transfusion. Indian J Med Res. 2019;149(1):34-40.

56. Dave K, Chinnakali P, Thekkur P, Desai S, Vora C, Desai G. Attrition from care and clinical outcomes in a cohort of sickle cell disease patients in a tribal area of Western India. Trop Med Infect Dis. 2019;4(4):125.

57. Somkuwar A, Bokade C, Merchant S, Meshram R, Mahalinge M, Somkuwar T. Short-term safety and beneficial effects of hydroxyurea therapy in children with sickle cell disease. Indian J Child Health. 2020;07:29-32.

58. Sinha S, Seth T, Colah RB, Bittles AH. Haemoglobinopathies in India: estimates of blood requirements and treatment costs for the decade 2017-2026. J Commun Genet. 2020;11(1):39-45.

59. Jain D, Tokalwar R, Upadhye D, Colah R, Serjeant GR. Homozygous sickle cell disease in Central India \& Jamaica: a comparison of newborn cohorts. Indian J Med Res. 2020;151(4):326-32.

60. Barma SK, Dash MR, Samal SR, Sethy G, Panigrahi P. Effect of hydroxyurea on clinical and haematological profile of children with sickle cell anaemia. Int J Res Rev. 2020;7(7):493-9.

61. Wong TE, Brandow AM, Lim W, Lottenberg R. Update on the use of hydroxyurea therapy in sickle cell disease. Blood. 2014;124(26):3850-7.

62. Roberts N, James S, Delaney M, Fitzmaurice C. The global need and availability of blood products: a modelling study. Lancet Haematol. 2019;6(12):e606-15.

63. Premawardhena A, Allen A, Piel F, Fisher C, Perera L, Rodrigo R, et al. The evolutionary and clinical implications of the uneven distribution of the frequency of the inherited haemoglobin variants over short geographical distances. Br J Hematol. 2017:176(3):475-84.

64. Uddin MM, Akteruzzaman S, Rahman T, Hasan AK, Shekhar HU. Pattern of $\beta$-thalassemia and other haemoglobinopathies: a cross-sectional study in Bangladesh. ISRN Hematol. 2012;2012:659191.

65. Khan W, Banu B, Sadiya S, Sarwardi G. Spectrum of types of thalassemias and hemoglobinopathies: study in a tertiary level children hospital in Bangladesh. Thalassemia Rep. 2017;7:1.

66. Gautam N, Gaire B, Manandhar T, Marasini BP, Parajuli N, Lekhak SP, et al. Glucose 6 phosphate dehydrogenase deficiency and hemoglobinopathy in South Western Region Nepal: a boon or burden. BMC Res Notes. 2019;12(1):734

67. Shrestha RM, Pandit R, Yadav UK, Das R, Yadav BK, Upreti HC. Distribution of hemoglobinopathy in Nepalese population. J Nepal Health Res Council. 2020;18(1):52-8.

68. Marchand M, Gill C, Malhotra AK, Bell C, Busto E, McKeown MD, et al. The assessment and sustainable management of sickle cell disease in the indigenous Tharu population of Nepal. Hemoglobin. 2017:41(4-6):278-82. 
69. Hussain J, Arif S, Zamir S, Mahsud M, Jahan S. Pattern of thalassemias and other hemoglobinopathies: a study in district Dera Ismail Khan. Pak Gomal Med J Sci. 2013;11:174-7.

70. Sameen D, Parveen S, Danish F, Salam H, Agha A, Sharafat S. Sickle cell anemia in sheedi population of lyari: hemoglobinopathy seen in a neglected population. Intjpathol. 2018;16(3):119-22.

71. Hashmi NK, Moiz B, Nusrat M, Hashmi MR. Chromatographic analysis of $\mathrm{Hb} \mathrm{S}$ for the diagnosis of various sickle cell disorders in Pakistan. Ann Hematol. 2008:87(8):639-45

72. Ware RE, Davis BR, Schultz WH, Brown RC, Aygun B, Sarnaik S, et al. Hydroxycarbamide versus chronic transfusion for maintenance of transcranial doppler flow velocities in children with sickle cell anaemiaTCD with transfusions changing to hydroxyurea (TWiTCH): a multicentre, open-label, phase 3, non-inferiority trial. Lancet (London, England). 2016;387(10019):661-70.

73. Opoka RO, Hume HA, Latham TS, Lane A, Williams O, Tymon J, et al. Hydroxyurea to lower transcranial Doppler velocities and prevent primary stroke: the Uganda NOHARM sickle cell anemia cohort. Haematologica. 2020;105(6):e272-5
74. Ware RE, Helms RW. Stroke with transfusions changing to hydroxyurea (SWiTCH). Blood. 2012;119(17):3925-32.

75. Alvarez O, Yovetich NA, Scott JP, Owen W, Miller ST, Schultz W, et al. Pain and other non-neurological adverse events in children with sickle cell anemia and previous stroke who received hydroxyurea and phlebotomy or chronic transfusions and chelation: results from the SWiTCH clinical trial. Am J Hematol. 2013;88(11):932-8.

76. Government of India MoHFW. Prevention and control of hemoglobinopathies in India -thalassemias, sickle cell disease and other variant hemoglobins. In: Mission NH, editor. New Delhi: Government of India, Ministry of Health \& Family Welfare; 2016. p. 83-6.

\section{Publisher's Note}

Springer Nature remains neutral with regard to jurisdictional claims in published maps and institutional affiliations.
Ready to submit your research? Choose BMC and benefit from:

- fast, convenient online submission

- thorough peer review by experienced researchers in your field

- rapid publication on acceptance

- support for research data, including large and complex data types

- gold Open Access which fosters wider collaboration and increased citations

- maximum visibility for your research: over $100 \mathrm{M}$ website views per year

At BMC, research is always in progress.

Learn more biomedcentral.com/submissions 